\title{
Analysis of Aeromagnetic Anomalies of the North-eastern Nigerian part of the Chad Basin
}

\author{
Kehinde S. Ishola, Blessing C. Okoye, Lukumon Adeoti, and Kayode F. Oyedele
}

Department of Geoscience, Faculty of Science, University of Lagos, Akoka, Nigeria

\section{Correspondence}

Kehinde S. Ishola, Department of Geosciences, Faculty of Science, University of Lagos,Akoka, Nigeria.

\section{Email:kishola@unilag.edu.ng}

All co-authors agreed to have their names listed as authors.

\section{Abstract:}

Aim: An appraisal of aeromagnetic data lying between Longitudes $11^{\circ} 00^{\prime}$ 25.95"E - $11^{\circ} 30^{\prime} 15.1^{\prime \prime} \mathrm{E}$ and Latitudes $11^{\circ} 30^{\prime} 7.59^{\prime \prime} \mathrm{N}-12^{\circ} 05^{\prime} 45.6 " \mathrm{~N}$ has been carried out with a view to understanding structural trends of interest as well as determination of depth to magnetic sources giving rise to magnetic anomalies in the study area.

Methodology: To achieve the objectives of this study, the aeromagnetic datasets were digitized along contours, corrected for the main geomagnetic field, re-gridded, and merged to generate magnetic structural anomaly map of the area. Also, from the aeromagnetic data, we used spectral technique based on Fourier transformation to estimate depths along some selected profiles on the residual anomaly map.

Results: The results show that the most pronounced structures are observed towards the southern and central parts of the study area signifying that majority of the magnetic anomalies trend in the NortheastSouthwest while the minor ones trend East-West direction. This suggests that the study area is intensely fractured with major regional faulting systems playing important role in entrapment and exploration of natural resources as well as understanding the hydrogeologic framework of the Basin. The spectral analysis shows mainly two depth magnetic sources, the deeper sources with depths in the range of 1.34 to $3.42 \mathrm{~km}$ while the shallow sources are observed at depths between 0.33 to $0.91 \mathrm{~km}$. Aeromagnetic data analysis over the basin shows that prominent anomalies have been identified and located.

Keywords: Aeromagnetic data, magnetic anomalies, spectral analysis, magnetic source, fracture, basin.

This is an open access article under the terms of the Creative Commons Attribution License, which permits use, distribution and reproduction in any medium, provided the original work is properly cited.

(c) 2018 The Authors. Journal of Research and Reviews in Science - JRRS, A Publication of Lagos State University 


\section{INTRODUCTION}

An interpretation of aeromagnetic data of North-eastern Nigerian sector of the Chad Basin (CB), which is an intra-continental basin owing its immediate origin to the existence of a number of peripheral uplifts [1] has been embarked upon. The CB with an area of about 230,000 $\mathrm{km}^{2}$ is the largest area of inland drainage in Africa [2, 3, 4] extending into parts of the Republics of Niger, Chad, Cameroon, Nigeria and Central Africa. The Nigerian sector of the CB known as Bornu Basin (BB) is about one-tenth of the $C B$ and with the exception of the popular Niger Delta Basin; it is the most explored in Nigeria [5]. A study of the BB is important as it is known to be one of the hydrocarbon basins in Nigeria.

Several geological and geophysical techniques are available for imaging subsurface geology. These include: gravity and magnetic, seismic, electrical methods (i.e., resistivity, induced polarization, self potential, electromagnetic, and ground penetrating radar) to mention but few. Magnetic method, however, has remained one of the most vital geophysical tools for understanding the subsurface geology. Magnetic survey is employed to investigate subsurface geology on the basis of variations of magnetic anomalies in the Earth's magnetic field resulting from the magnetic properties of the underlying rocks $[6,7]$. A geophysical survey performed as airborne is known as aeromagnetic survey (AES). AES are geophysical data acquired from aircraft that measures the subtle variations in the Earth's magnetic field because of the differences in the magnetic properties of the underlying rocks. All rock units are magnetic but not all the rock materials do give rise to magnetic effects which are easily noticed [8].

The essence of acquisition of AES is to help in solving the problems of regional geological mapping and structure, delineation of buried contacts, mineralization and thickness of sedimentary cover $[9,10,11]$. The speed of operation and cost make such surveys very attractive especially if it is intended to assist in mineral and hydrogeologic framework through geologic mapping. Other reasons for performing AES especially over a sedimentary terrain are to delineate the configuration of the basin, provide relevant information on depth, lateral extents of sediments deposited, and location of fracture or faults [10]. Elsewhere, AES has been applied at the early stage of petroleum exploration to determine depth and major structure of crystalline basement rocks underlying sedimentary basins $[7,12]$.

The Nigerian Geological Survey Agency (NGSA) in an effort to achieve the aforementioned goals has been acquiring aeromagnetic data across Nigeria for over three decades. The magnetic maps produced have been used to understand, determine trends, extents, and geometries of the magnetic bodies in a particular area. Several research works have been reported in the literature in respect to the use of aeromagnetic data sets for deciphering the subsurface geology. [13] used magnetic gradient techniques to identify possible subsurface structures of the Gulf of Suez Basin in Egypt for promising prospects for hydrocarbon exploration using.

In another work, [14] used aeromagnetic data acquired in California to examine the Curie-isotherm depths from magnetic anomalies using power-density spectrum. [15] used high resolution aeromagnetic data complemented with gravity data sets obtained through satellite to structurally characterize the Benin Basin for its geopotential field attributes. Furthermore, [16] reviewed igneous intrusion processes linked with crustal elongation and discovered that a major igneous body as intrusive along the direction of elongation. [17] demonstrated how magnetic anomalies from bodies at different depths where separated in order to determine the depth to each body.

In this paper, aeromagnetic data sets which cover the Nigerian's sector of the CB were interpreted and analyzed in order to map the subsurface magnetic structures and estimate the depth of the magnetic sources using spectral technique. Sequel to this, knowledge of the structural mechanisms of the $C B$ which from time immemorial has continued to attract attention among prominent researchers in respect to its prospectivity mapping is gained.

\section{LOCATION AND GEOLOGICAL SETTINGS}

The study areas Damaturu, Dapchi, Birin, and Potiskum are in Yobe State, Nigeria and lie between Latitudes $11^{\circ}$ $30^{\prime} 7.59^{\prime \prime} \mathrm{N}-12^{\circ} 05^{\prime} 45.6^{\prime \prime} \mathrm{N}$ and Longitudes $11^{\circ} 00^{\prime} 25.9^{\prime \prime}$ $\mathrm{E}-11^{\circ} 30^{\prime} 15.1^{\prime \prime} \mathrm{E}$.

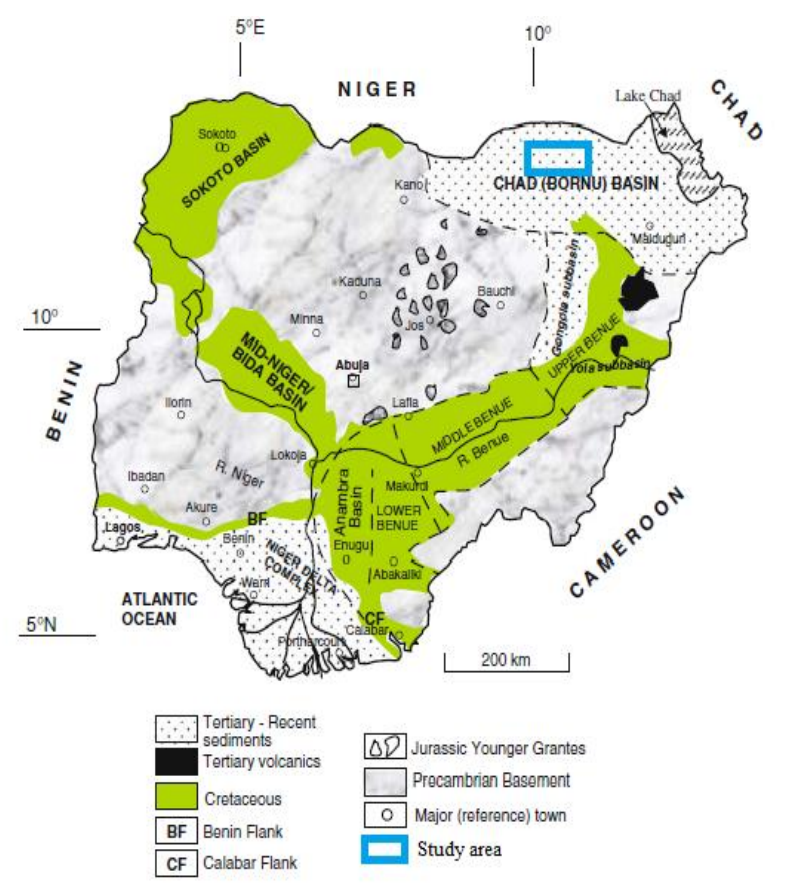

Fig. 1 Geological map of Nigeria showing the study

area modified after [5] 


\subsection{Tectonic setting}

The four main tectonic units of the BB were well documented in [18]. They are (i) the Pan African Crustal consolidation stage, where during this era, major basement lineaments and faults were produced with the dominant fault trending NE-SW [4] (ii) the Early rift stage which belonged to the period $(130-98 \mathrm{Ma})$ on the geological scale and it was during this period that the rift basin was formed. The Benue Trough and Bornu Basin were reported formed during the break-up of the Gondwanaland [18, 19] (iii) the Late Rift stage that lasted between 98 - 75 Ma witnessed a slowdown in rift development as a result of changes in the stress regime caused by variations in the spreading rate of tectonocustic rise in sea level to epicontinental transgression [18] (iv) the Post Rift Stage $(66$ - 0) Ma no major tectonic activity such as faulting and folding took place.

\subsection{Lithostratigraphy}

The geology of BB of which the study areas belong has been well documented in earlier works of [20, 21, 22, 23]. The stratigraphy of BB has been widely studied by $[24,25,26,4]$. The sediments were deposited within the rift system. The sedimentary fills in most parts of the basin were made of Late Cenozoic-middle Eocene continental sediments, Cretaceous and Tertiary series accumulating preferentially in tectonic rifts [5]. Geophysical and boreholes data gathered from adjacent basins have indicated that BB is made up of five stratigraphic units. This includes: the Bima Sandstone at the bottom, the Gongila Formation, and the Fika Shale. Others are the Keri-Keri and Chad Formations [5]. In most cases the Chad Formation which is a variable succession that includes all Quaternary sediments underlying the surface deposits lies directly uncomfortably on the Fika Shale [22, 27].

\section{THEORETICAL BACKGROUND OF SPECTRAL METHOD}

Spectral technique in recent years has become a widely utilized tool for processing and interpretation of potential field data [28, 29, 30, 31]. It is well suited for analyzing aeromagnetic maps and profiles. Most often, images of a particular investigation are poorly presented due to noise and measurement errors. In situation where noise and measurements errors couldn't be ignored, some features of the data sets are needed to be enhanced for better visualization and interpretation. As a result, further analyses of the images are required for better correlation, improvement and enhancement purposes. Among the several techniques available for these purposes, is the Discrete Fourier Transformation (DFT). DFT is applicable to data which are spaced regularly such as the aeromagnetic data. The Fourier Transform is summarized as:

$$
\begin{aligned}
& P_{i(x)}=\sum_{m=1}^{N}\left[a_{m} \cos \left(\frac{2 \pi m x_{i}}{L}\right)+\right. \\
& \left.b_{m} \sin \left(\frac{2 \pi m x_{i}}{L}\right)\right]
\end{aligned}
$$

where:

$P_{i}(x)=$ reading at $x_{i}$ position

$L=$ length of the cross section of the anomaly $\mathrm{m}=$ harmonic number of the partial wave

$N=$ number of data points

$a_{m}=$ real part of the amplitude

$b_{m}=$ imaginary part of the amplitude

$i=0,1,2,3, \ldots \ldots \ldots, m$

But,

$$
\begin{gathered}
a_{m}=\frac{2}{N} \sum_{i=1}^{N} P_{i} \cos \frac{2 \pi m x_{i}}{L} \\
b_{m}=\frac{2}{N} \sum_{i=1}^{N} P_{i} \sin \frac{2 \pi m x_{i}}{L}
\end{gathered}
$$

Plots obtained using computed values of $A_{m}$ represent the graphs of natural logarithm of the amplitude $\left(A_{m}\right)$ against frequency $(\mathrm{m})$. From the graph, a linear segment of the low and high frequencies portions of the spectrum represents contribution from the causative bodies that are deep-seated and shallow structures respectively. However, an evaluation of the gradient of the linear segment using Equ. 5 represents the depth to the basement [34]. Thus, the DFT technique filters the noise from a particular aeromagnetic data [35].

$$
z=-M L / 2 \pi
$$

where:

$z=$ depth to the magnetic sources basement

$M=$ gradient of the linear segment

$L=$ width of the anomaly

\section{MATERIAL AND METHODS}

The study covered a total area of approximately 12,000 $\mathrm{km}^{2}$ and aeromagnetic sheets obtained from NGSA were used. The sheets are shown in Fig. 2. Each square sheet of dimensions $55 \times 55 \mathrm{~km}^{2}$ represents a contoured map in the scale of $1: 100,000$. The sheets used and analyzed contained the magnetic data obtained along a series of Northwest-Southeast flight lines with a spacing of $2 \mathrm{~km}$. The average flight elevation was about $150 \mathrm{~m}$ while the tie lines were about $20 \mathrm{~km}$ interval. The different aeromagnetic data sets were gridded and combined, maps were prepared, spectral analysis and interpretations were carried out using Surfer-32 and Geosoft platforms of Oasis Montaj softwares. The International Geomagnetic Reference Field (IGRF) was used to separate the regional geomagnetic gradient from the magnetic datasets. Since the aeromagnetic data sets contained both the regional and residual anomalies known as the total magnetic field intensity (TMI).Then, we applied a multiple regression technique by fitting a linear trend surface on to the digitized aeromagnetic data so as to remove the regional effect. This was done in accordance with the procedures used in [36]. The generated magnetic anomaly maps were interpreted both qualitative and quantitatively. Qualitatively, visual inspection of the total magnetic field intensity map was carried out. The three features keyed in qualitative interpretation were: (i) structural trend defined by sharp changes in contour gradient (ii) faulting suggested by the alignment of lateral shift that offset the main anomaly and (iii) the presence of magnetic bodies suggested by the alignment of closed anomalies. For the quantitative interpretations, five cross sections $A A^{1}$ - EE ${ }^{1}$ were taken on the residual anomaly map. In depth 
estimation using spectral method, an important aspect was to remove the regional effect from the map of the total field which is a time domain data. Then, the total field was transformed to the frequency domain, and the energy spectrum was calculated from the complex Fourier amplitude spectrum. Finally, plots of the logarithm of the energy versus radial frequency were obtained.

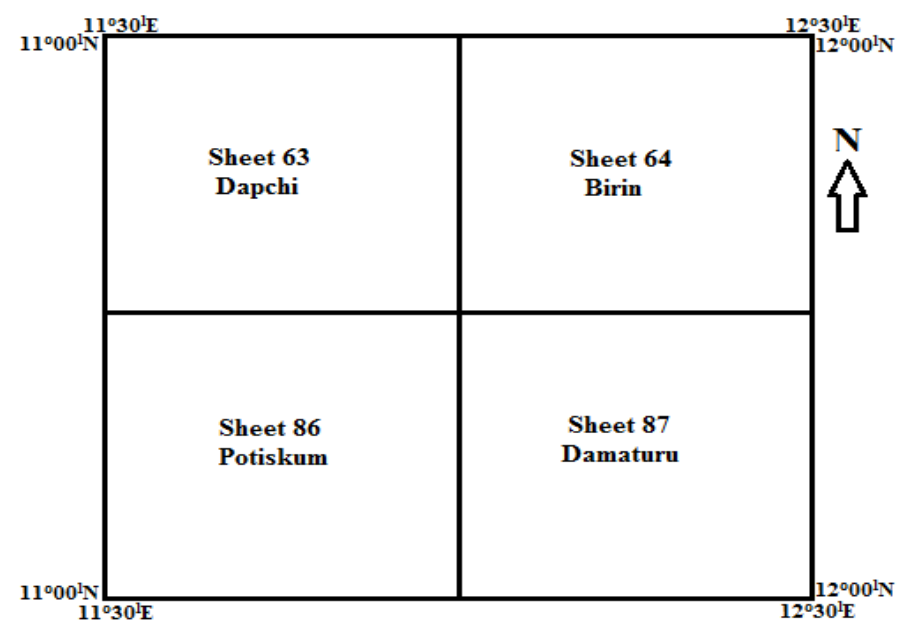

Fig. 2 Aeromagnetic sheets of the study area

\section{RESULTS AND DISCUSSION}

The total magnetic intensity (TMI) map obtained for the study area is shown in Fig. 3. It shows that there is a huge magnetic anomaly of order of magnitude between 8550 and $9380 \mathrm{nT}$ around Birin area which is Northeastern (NE) part of the study area. In the southern parts of the map, small size anomalies ranging from 7655 to $7730 \mathrm{nT}$ are delineated. Also, observed is that the Dapchi area of North-western (NW) part of the map have extensive magnetic anomaly with highest intensity of $7925 \mathrm{nT}$. The residual anomalies map (RAM) of the study area showing the presence of magnetic anomalies is shown in Fig. 4. The magnetic anomalies are characterized by both positive and negative values of $325 \mathrm{nT}$ (as highest) and $-425 \mathrm{nT}$ (as lowest) at the western part of the area respectively. Moreover, in the eastern and southern parts of the study area, the presence of faults or local fractured zones suggested by linear sub-parallel orientation of contours which are closely spaced with majority of the anomalous bodies trending in the Northeast-Southwest (NE-SW) directions while minor ones trend in East-West (E-W) directions are observed.

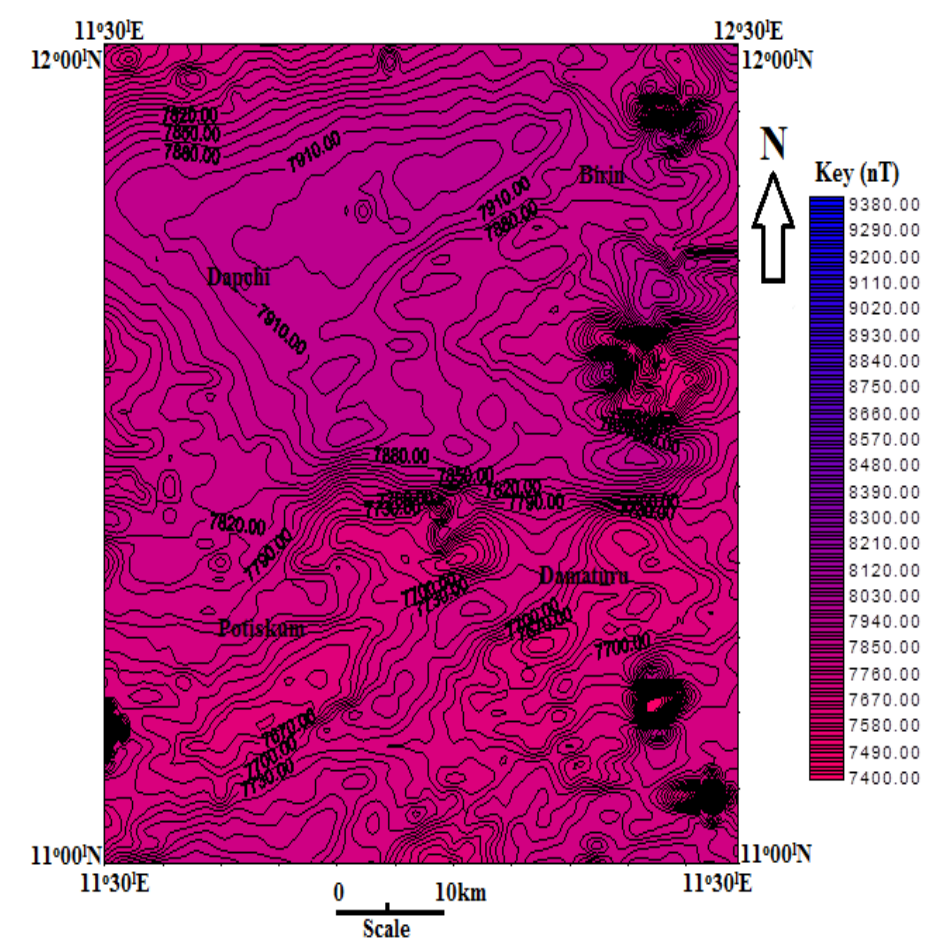

Fig. 3 Total Magnetic Intensity map of the study area

[37] suggested that there would always be a magnetic susceptibility contrast across a fracture zone due to oxidation of magnetite to hematite, and/or infilling of fracture planes by dyke-like bodies whose magnetic susceptibilities are different from those of their host rocks. Such geologic features may appear or are seen as thin elliptical closures or nosing on the aeromagnetic maps.

\section{Fig. 4 Residual Anomaly map of the study area with profile lines}

The shape of the anomaly contains information on depth to source of the anomaly. The depth to source referred to as depth to the magnetic basement is of significance when thick layer of consolidated or

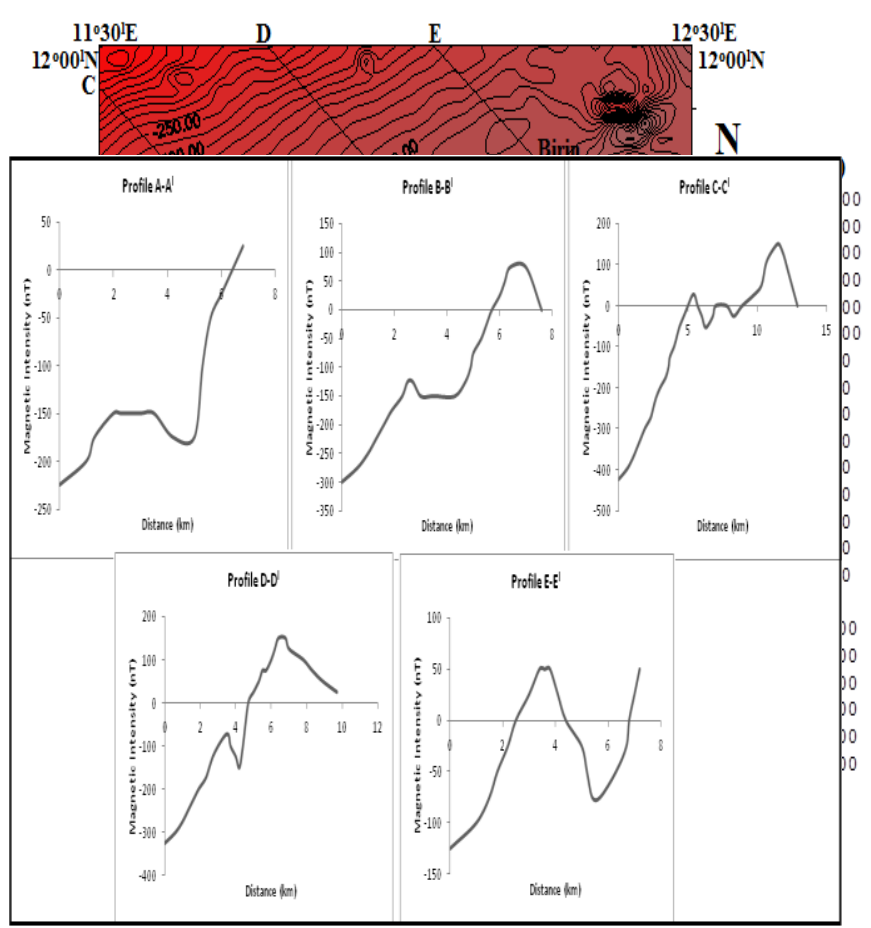


unconsolidated overburden covers potential mineral deposits. The results of Fourier transform technique utilized for estimation of depths to basement across the selected five profiles on the RAM is shown in Fig. 5. The plot of natural logarithm of the amplitude against frequency obtained from the five profiles drawn across the RAM is shown in Fig. 6. It shows the linear segments obtained for the amplitude spectra derived by transforming the digitized magnetic data to the frequency domain by Fourier transform.

\section{Fig. 5 Plot of selected profiles within the study area}

Analysis of frequency domain magnetic data shows that the spectral responses of deep and shallow magnetic sources are clearly different. The linear segments show that the slopes are negatives since the logarithm of amplitude of the magnetic anomaly decreases with an increasing frequency. The slope of the line segment gives direct estimate of depth to the magnetic source. Magnetic responses of shallow sources are characterised by high amplitude and short wavelength anomalies which correspond to the upper line segments in Fig. 6. The contributions of deep-seated sources are evident in the low amplitude portion of the spectra. However, the points shown outside the line segments represent cultural noise [38]. The estimated depths to magnetic sources are presented in Table 1. The basement depths along profile $A-A^{1}$ ranges from 0.58 $3.21 \mathrm{~km}$, along $B-B^{1}$ the depths range from $0.45-3.08$ $\mathrm{km}, 0.76-3.42 \mathrm{~km}$ along $\mathrm{C}-\mathrm{C}^{1}$, along profiles $\mathrm{D}^{-\mathrm{D}^{1}}$ and $E-E^{1}$ the depths range from $0.33-2.63 \mathrm{~km}$ and 0.62 $1.79 \mathrm{~km}$ respectively. The deeper magnetic sources ranging from $1.34-3.42 \mathrm{~km}$ has an average of $2.51 \mathrm{~km}$ and the shallower magnetic sources range from 0.33 $0.91 \mathrm{~km}$ with an average of $0.68 \mathrm{~km}$ are the two depth sources obtained from the spectral analysis result. Also, the average sedimentary thickness is estimated as $2.51 \mathrm{~km}$ for the study area. According to [39, 37, 11, 40] their results revealed that the sedimentary thicknesses for the Nigeria sector of the Chad Basin ranges between $0.6-5.2 \mathrm{~km}$. These results agree with the estimated depth obtained in this study. In addition, the trend of prominent magnetic anomalous features within the study area is in Northeast-Southwest (NE-SW) while the minor ones are in East-West $(\mathrm{E}-\mathrm{W})$ directions. This also agrees with [1] that the study area is associated

with the extensional tectonics which affects the region from the Benue Trough to the Chad Basin.

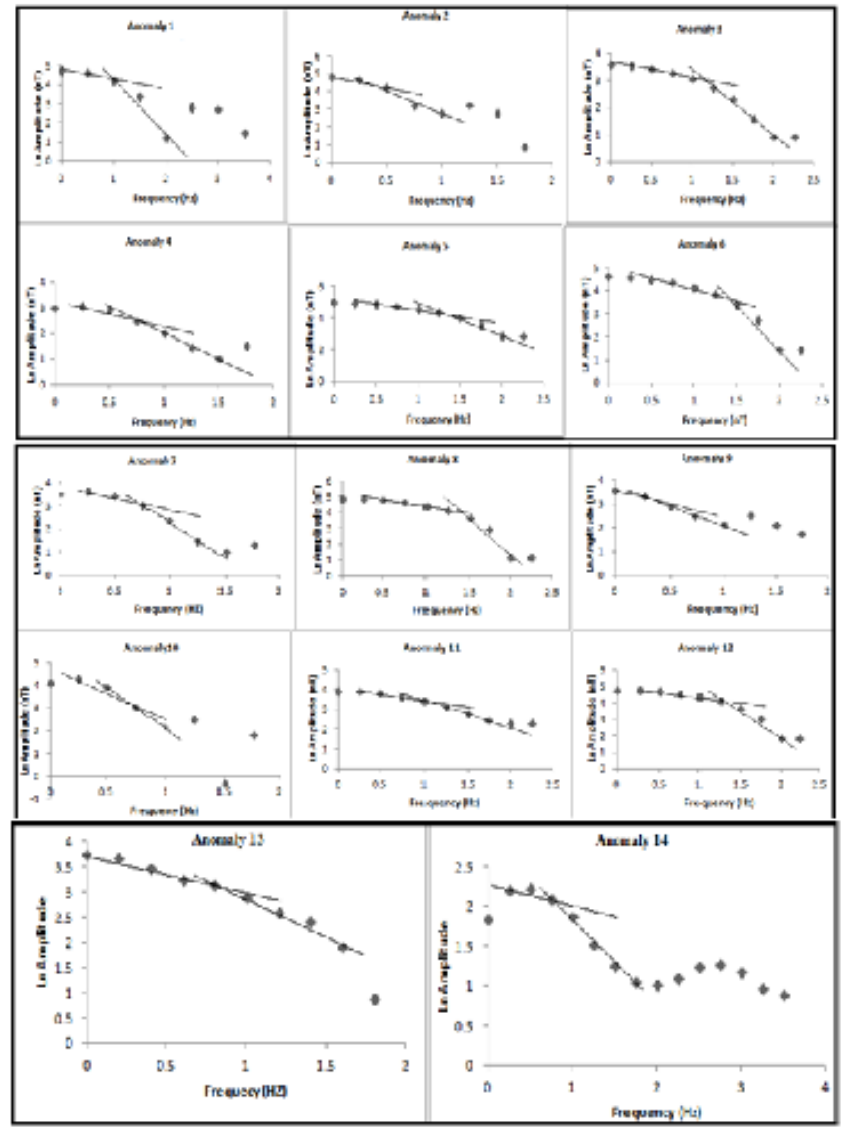

Fig. 6 Amplitude spectra for all analyzed anomalies within the study area.

Table 1 Depth to Basement obtained from Spectral Analysis

\begin{tabular}{|c|c|c|c|c|}
\hline $\begin{array}{l}\text { Profile } \\
\text { name }\end{array}$ & $\begin{array}{l}\text { Profile } \\
\text { direction }\end{array}$ & Anomaly & $\begin{array}{l}\text { Shallower } \\
\text { Depth } \\
(\mathrm{km})\end{array}$ & $\begin{array}{l}\text { Deeper } \\
\text { Depth } \\
(\mathrm{km})\end{array}$ \\
\hline \multirow[t]{4}{*}{$A-A^{\prime}$} & NW-SE & 1 & 0.58 & 3.21 \\
\hline & NW-SE & 2 & 0.74 & 2.91 \\
\hline & NW-SE & 3 & 0.72 & 2.74 \\
\hline & NW-SE & 4 & 0.91 & 1.34 \\
\hline \multirow[t]{3}{*}{$B-B^{\prime}$} & NW-SE & 5 & 0.45 & 2.93 \\
\hline & NW-SE & 6 & 0.63 & 3.08 \\
\hline & NW-SE & 7 & 0.89 & 2.01 \\
\hline \multirow[t]{2}{*}{$C-C^{\prime}$} & $\begin{array}{l}\text { NW-SE } \\
\text { NW-SE }\end{array}$ & $\begin{array}{l}8 \\
9\end{array}$ & $\begin{array}{l}0.76 \\
0.82\end{array}$ & $\begin{array}{l}2.84 \\
3.42\end{array}$ \\
\hline & NW-SE & 10 & 0.33 & 1.38 \\
\hline \multirow[t]{2}{*}{$D-D^{\prime}$} & NW-SE & 11 & 0.67 & 2.63 \\
\hline & NW-SE & 12 & 0.91 & 3.33 \\
\hline
\end{tabular}




\begin{tabular}{lcccc} 
E-E & NW-SE & 13 & 0.42 & 1.58 \\
& NW-SE & 14 & 0.62 & 1.79 \\
\hline Average & & & 0.68 & 2.51 \\
\hline
\end{tabular}

\section{CONCLUSION}

For this study, structural information relating to geomagnetic responses of the subsurface heterogeneous geology of the study area has been presented thus expanding the web of knowledge of the structural mechanisms of the basin. The majority of the magnetic anomalies are observed to trend NortheastSouthwest while minor ones trend East-West directions indicating that the study area is characterized by major regional faults trending in NE-SW direction. It is believed that these faulting systems could significantly assist in the entrapping and explorations of minerals and hydrocarbons potentials in the area. Essentially, the two depth magnetic sources estimated are the deeper sources and the shallower sources. The linear depression observed at the southern and central parts of the study area indicates thicker sediments which trend northwest-southeast direction while shallower sedimentary thicknesses are found in the northern parts.

\section{ACKNOWLEDGEMENTS}

We would like to thank the anonymous reviewers for their suggestions and comments. Following their suggestions, we included several improvements in the manuscript.

\section{COMPETING INTERESTS}

There is no competing interest.

\section{AUTHORS' CONTRIBUTIONS}

Kehinde Ishola: supervised the study, helped in analyzing the results and wrote the first draft of the manuscript.

Blessing Okokye: obtained the data, processed and interpreted the results

Lukumon Adeoti: proofread and revised the manuscript. Kayode Oyedele: proofread and revised the manuscript.

All authors read and approved the final manuscript.

\section{REFERENCES}

[1] Anakwuba, E.K., Onwuemesi, A.G., Chinwuko, A. I., \& Onuba, L. N.(2011). The Interpretation of Aeromagnetic anomalies over Maiduguri Dikwa depression, Chad Basin Nigeria: A Structural View. Scholars research library. Archives of Applied Science Research, 3(4), 499-508.
[2] Barber, W. (1965). Pressure water in the Chad Formation of Borno and Dikwa Emirates, Northeastern Nigeria. Geological Survey of Nigeria Bulletin (35), 138-139.

[3] Matheis, G. (1975). Short Review of the Geology of the Chad Basin, In: Kogbe,C.A.(Ed.) Geology of Nigeria. Elizabithan Publishing Co. Lagos, 241-346.

[4] Avbovbo, A. A., Ayoola, E. O., \& Osahon, G. A. (1986). Deposition and structural styles in the Chad Basin of Northeastern Nigeria. American Association of Petroleum Geologists Bulletin, 70(12), 1787-1798.

[5] Obaje, N.G. (2009). The Bornu Basin Nigerian Sector of the Chad Basin. Geology and mineral of Nigeria, 120, $69-76$.

[6] Lilley, F.E.M., Hitchman, A.P., \& Wang, L.J. (1999). Time-varying effects in magnetic mapping: Amphidromes, doldrums, and induction hazard: Geophysics, 64, 1720-1729.

[7] Ikumbur, E. B., Onwuemesi, A. G., Anakwuba, E. K., Chinwuko, A. I., Usman, A.O., \& Okonkwo, C. C. (2013). Spectral Analysis of Aeromagnetic Data over Part of the Southern Bida basin, West-Central Nigeria. International Journal of Fundamental Physical Sciences, 3, (2), 27-31.

[8] Gunn, P.J. (1997a). Application of aeromagnetic surveys to sedimentary basin studies. AGSO Journal Australian Geology and Geophysics. 17(2), 133-144.

[9] Domzalski, W. (1966). Importance of aeromagnetic in evaluation of structural control of mineralization. Geophys. Prospect. XIV (3), 273-291.

[10] Glenn, W.E., Rhodes, J.A., Goussev, S.A., Benedict, M.L., Charters, R.A., Peirce, J.W., \& Genereux, J.(2002).Aeromagnetic Depth Solutions Indicate Numerous Magnetic Sources within the Sedimentary Section of the Western Canada Sedimentary Basin. CSEG Geophysics.

[11] Chinwuko, A. I., Onwuemesi, A. G., Anakwuba, E. K., Okeke, H. C., Onuba, L.N., Okonkwo, C.C., \& Ikumbur, E. B. (2013). Spectral Analysis and Magnetic Modeling over Biu Damboa, Northeastern Nigeria. IOSR Journal of Applied Geology and Geophysics, 1(1), 2028.

[12] Ofor, N.P., \& Udensi, E.E. (2014). Determination of the heat flow in the Sokoto Basin, Nigeria using spectral analysis of 
aeromagnetic data. Journal Natural Science Research, 4(6), 34 - 40.

[13] Aboud, E., Salem, A., \& Ushijima, K. (2003). Interpretation of Aeromagnetic Data of Gebel El-Zeit Area, Gulf of Suez, Egypt Using Magnetic Gradient Techniques. Memoirs of the Faculty of Engineering, Kyushu University, 63(3), 139-149.

[14] Ross, H.E., Blakely, R.J., \& Zoback, M.D. (2006). Testing the use of aeromagnetic data for the determination of Curie depth in California. Geophysics, 71(5), L51-L59.

[15] Oladele, S., Ayolabi, E.A., \& Dublin-Green, C.O. (2016). Structural characterization of the Nigerian sector of Benin Basin using geopotential field attributes. Journal of African Earth Sciences 121, 200-209.

[16] Gunn, P.J. (1997b). Regional gravity and magnetic responses of extensional sedimentary basins. AGSO Journal of Australian Geology \& Geophysics, 17(2), 153162.

[17] Odegard, M.E., \& Berg, J.W. (1965). Gravity interpretation using the Fourier integral, Geophysics, XXX, 3, 424-38.

[18] Genik, G. J. (1992). Regional framework, structural and petroleum aspects of rift basins in Niger, Chad and the Central African Republic. Tectonophysics, 213, 169-185.

[19] Fairhead, J.D., \& Blinks, R.M. (1991). Differential opening of the west central and south Atlantic oceans and the opening of the West Africa rift system. Tectonophysics, 187, 191-203.

[20] Falconer, J.D. (1911). The Geology and Geography of Northern Nigeria. Macmillan, London.

[21] Okosun, E. A. (2002). A preliminary assessment of the petroleum potential of the Southwest Chad Basin, Nigeria. Nigeria Journal of Technological Research 1:87-94.

[22] Carter, J.D., Barber, W., \& Jone, G.P. (1963). The geology of parts of Adamawa, and Bornu provinces in Northeastern Nigeria, Bull. Geol. Surv. Nigeria. 30,109.

[23] Avbovbo, A.A. (1980). Basement geology in the sedimentary basins of Nigeria. Geology, 8, 323-327.

[24] Adegoke, O.S., Jan du Chene, R.E., Agumanu, E.A., \& Ajayi, P.O. (1978). Palynology and age of the Kerikeri Formation, Nigeria. Nigeria RevistaEspanolaMicropal. 10 (2), 249-277.
[25] Petters, S.W. (1982). Central West African Cretaceous-Tertiary benthic Foraminifera and stratigraphy. Palaeontographica Abt. A. 179, 1104.

[26] Kogbe, C.A. (1979). Geology of Nigeria, Elizabethan Pub. Co. Lagos. 436.

[27] Dike, E.F.C. (2002). Some aspects of basin analysis, petroleum geology and hydrogeology of Borno Basin, NE Nigeria. NAPE International Conference and Exhibition, Eko Meridien Hotel, Lagos. 15.

[28] Spector, A., \& Grant, F. S. (1970). Statistical models for interpreting aeromagnetic data, Geophysics, 35, 293-302.

[29] Bhattacharyya, B. K. \& Leu, L. K. (1977). Spectral analysis of gravity and magnetic anomalies due to rectangular prismatic bodies, Geophysics, 42, 41-50.

[30] Shuey, R. T., Schellinger, D. K., Tripp, A. C., \& Alley, L. B. (1977).Curie depth determination from aeromagnetic spectra, Geophys. J. Roy. Astr. S., 50, 75-101.

[31] Nabi, S. H. A. (2012). Curie point depth beneath the Barramiya-Red sea coast area estimated from spectral analysis of aeromagnetic data, J. Asian Earth Sci., 43, 254-266.

[32] Davis, J.C. (1973). Statistics and Data Analysis in Geology. John Wiley and Sons, New York, USA.

[33] Spector, A., \& Grant, F. S. (1970). Statistical models for interpreting aeromagnetic data, Geophysics, 35, 293-302.

[34] Negi, J.G., Agrawal, P.K., \& Rao, K.N.N (1983). Three dimensional Model of the Moyan area of Maharshiatra state (India) based on the spectral analysis of aeromagnetic data. Geophysics, 48(7), 964-974.

[35] Telford, W.M., Geldart, L.P., \& Sheriff, R.E. (1990). Applied Geophysics (2 Ed.). Cambridge University Press, USA.

[36] Chukwunonso, O.K., Godwin, O.A., Kenechukwu, E.K., Ifeanyi,C.A., Ikumbur, I.B., \& Ojonugwa, U.A. (2012). Aeromagnetic Interpretation over Maiduguri and Environs of Southern Chad Basin, Nigeria. Journal of Earth Sciences and Geotechnical Engineering, 2(3), 77- 93.

[37] Chinwuko, A.I., Onwuemesi, A.G., Anakwuba, E.K., Onuba, L.N., \& Nwokeabia, N.C. (2012). The Interpretation of Aeromagnetic Anomalies 
over parts of Upper Benue Trough and Southern Chad Basin, Nigeria. Advances in Applied Science Research, 3(3), 1757-1766.

[38] Onwuemesi, A.G. (1997). One Dimensional Spectral Analysis of Aeromagnetic Anomalies and Curie Depth Isotherm in the Anambra Basin of Nigeria. Journal of Geodynamics, 23 (2), 95-107.

[39] Anakwuba, E., \& Chinwuko, A. (2012). ReEvaluation of Hydrocarbon Potentials of Eastern Part of the Chad Basin, Nigeria: An Aeromagnetic Approach. Search and Discovery Article \#10405; Adapted from extended abstract prepared in conjunction with poster presentation at AAPG Annual Convention and Exhibition, Long Beach, California.

[40] Okonkwo, C. C., Onwuemesi, A. G., Anakwuba, E. K., Chinwuko, A. I., Ikumbur B.
E., \& Usman, A. O., (2012). Aeromagnetic Interpretation over Maiduguri and Environs of Southern Chad Basin, Nigeria. Journal of Earth Sciences and Geotechnical Engineering, 2(3), 77-93.

[41] Anakwuba, E.K., Onwuemesi, A.G., Chinwuko, A. I. and Onuba, L. N. (2011). The Interpretation of Aeromagnetic anomalies over Maiduguri Dikwa depression, Chad Basin Nigeria: A Structural View. Scholars research library. Archives of Applied Science Research, 3(4), 499-508. 